\title{
Komunikasi Keluarga Dalam Pencegahan Coronavirus Disease 2019
}

\author{
Sitti Murni Kaddi', Puji Lestari' ${ }^{2}$, Donal Adrian ${ }^{3}$ \\ ${ }^{1,3}$ Program Studi Ilmu Komunikasi, Fakultas Ilmu Sosial dan Ilmu Politik, Universitas Tadulako \\ Jl Soekarno Hatta, KM 9, Tondo, Kota Palu, Sulawesi Tengah, 94148, Indonesia \\ ${ }^{2}$ Program Studi Ilmu Komunikasi, Fakultas Ilmu Sosial dan Ilmu Politik, \\ Universitas Pembangunan Nasional "Veteran" Yogyakarta \\ Jl. Babarsari No. 2 TambakbayanYogyakarta, 55281, Indonesia \\ Email: unni_kaddi@yahoo.com ${ }^{1 *}$; puji.lestari@upnyk.ac.id²; donal.adrian2014@gmail.com³ \\ *Corresponding author
}

\begin{abstract}
The transmission of Coronavirus Disease 2019 (COVID-19) is beginning to threaten the smallest social unit, namely the family cluster. This study aims to analyze the benefits of family communication in preventing COVID-19 in the people of Nupabomba Village as the border area of Donggala Regency and Palu City. This study uses qualitative methods with interview data collection techniques and field observations. The results showed that family communication used by parents and children was very useful in preventing the spread of COVID-19 in Central Sulawesi. The process of delivering messages related to the dangers of COVID-19 by parents can change children's understanding and behavior so that preventive action occurs. This is done because it considers that the information related to the virus is very important, if it is ignored it will cause the body to become slightly ill to death. Prevention is carried out such as diligently washing hands, wearing masks, not touching, and maintaining distance, such as staying away from migrants or other communities passing through Nupabomba Village. This research contributes to the form of policy proposals for each family to socialize various positive things in reducing the risk of COVID-19 by opening air currents, regulating masked interactions, and maintaining distance.
\end{abstract}

Keywords: COVID-19; Family Communication; Nupabomba Village

\begin{abstract}
Abstrak
Transmisi Coronavirus Disease 2019 (COVID-19) mulai mengancam unit sosial terkecil, yaitu klaster keluarga. Penelitian ini bertujuan untuk menganalisis manfaat komunikasi keluarga dalam pencegahan COVID-19 pada masyarakat Desa Nupabomba sebagai daerah perbatasan Kabupaten Donggala dan Kota Palu. Penelitian ini menggunakan metode kualitatif dengan teknik pengumpulan data wawancara dan observasi di lapangan. Hasil penelitian menunjukkan bahwa komunikasi keluarga yang digunakan oleh orangtua dan anak sangat bermanfaat dalam mencegah terjadinya penyebaran COVID-19 di Sulawesi Tengah. Proses penyampaian pesan terkait dengan bahaya COVID-19 yang dilakukan orangtua dapat mengubah pemahaman dan perilaku anak sehingga terjadilah tindakan pencegahan. Hal ini dilakukan karena menganggap bahwa informasi terkait dengan virus tersebut sangat penting, apabila diabaikan menyebabkan tubuh menjadi sakit ringan hingga pada kematian. Pencegahan yang dilakukan seperti rajin mencuci tangan, memakai masker, tidak bersentuhan dan menjaga jarak, seperti menjauhi para pendatang atau masyarakat lain yang melewati Desa Nupabomba. Penelitian ini memberikan kontribusi berupa usulan kebijakan kepada setiap keluarga untuk menyosialisasikan berbagai hal positif dalam pengurangan risiko COVID-19 dengan cara buka aliran udara, atur interaksi bermasker, dan jaga jarak.
\end{abstract}

Kata Kunci: COVID-19; Komunikasi Keluarga; Desa Nupabomba

\section{Pendahuluan}

COVID-19 merupakan virus yang banyak ditakuti oleh sebagian besar masyarakat dunia karena dapat mengakibatkan kematian dan tentunya membatasi interaksi sosial kehidupan antar manusia. Pada Desember 2019, kasus pneumonia misterius pertama kali dilaporkan di Wuhan, Provinsi Hubei. Pada 18 Desember hingga 29 Desember 2019, terdapat lima pasien yang dirawat dengan Acute Respiratory Distress Syndrome (ARDS) (Rubson, 2020). Sejak 31 Desember 2019 hingga 3 Januari 2020 kasus ini meningkat pesat, ditandai dengan dilaporkannya sebanyak 44 kasus. Tidak sampai satu bulan, 
penyakit ini telah menyebar di berbagai provinsi lain di China, Thailand, Jepang, dan Korea Selatan, (Huang, 2020). Sampel yang diteliti menunjukkan etiologi coronavirus baru. Pada awalnya, penyakit ini dinamakan sementara sebagai 2019 novel coronavirus (2019-nCoV), kemudian WHO mengumumkan nama baru pada 11 Februari 2020 yaitu Coronavirus Disease 2019 (COVID-19) yang disebabkan oleh virus Severe Acute Respiratory Syndrome Coronavirus-2 (SARS-CoV-2) (World Health Organization, Maret 2020).

Berdasarkangejalayangterlihatbahwa secara umum infeksi COVID-19 dapat mengganggu pernapasan akut seperti demam, batuk, dan sesak napas. Masa inkubasi rata-rata 5- 6 hari dengan masa inkubasi terpanjang 14 hari. Pada tanggal 30 Januari 2020 WHO telah menetapkan sebagai kedaruratan kesehatan masyarakat yang meresahkan dunia, (Dewi, 2020: 56). Proses penyebaran COVID-19 ditularkan dari manusia ke manusia yang secara luas awalnya terjadi di Cina dan lebih dari 190 negara lainnya (World Health Organization, Maret 2020). Pada 29 Maret 2020, terdapat 634.835 kasus dan 33.106 jumlah kematian di seluruh dunia, sedangkan di Indonesia sudah ditetapkan 1.528 kasus dengan positif COVID-19 dan 136 kasus kematian (Susilo, 2020:45). Hal tersebut memperlihatkan bahwa penyebaran COVID-19 tidak dapat dianggap remeh, percepatan penyebarannya hanya berlangsung dalam kurun waktu 4 bulan dari bulan Desember 2019 - Maret 2020.

Tidak hanya berkaitan dengan dampak negatif yang dapat menyerang tubuh manusia, namun COVID-19 dapat membuat manusia membatasi pergerakan sosial, misalnya dalam dunia pendidikan. Berdasarkan laporan $\mathrm{ABC}$ News 7 Maret 2020, penutupan sekolah terjadi di lebih dari puluhan negara karena wabah COVID-19. Menurut data Organisasi Pendidikan, Keilmuan, dan Kebudayaan PBB (UNESCO), setidaknya ada 290,5 juta siswa di seluruh dunia yang aktivitas belajarnya menjadi terganggu akibat sekolah yang ditutup (Smith \& Jones, 2004). Di tingkat perguruan tinggi Amerika serikat, wabah virus corona juga menunjukkan intervensinya, sehingga program pertukaran mahasiswa antarnegara harus dihentikan. Kondisi Italia yang merana karena COVID-19, beberapa universitas meminta seluruh mahasiswanya kembali dari program study exchange di Italia. Kebijakan ini menyusul keputusan Pusat Pencegahan dan Pengendalian Penyakit (CDC) yang menempatkan Italia dari status darurat Level 2 ke Level 3 pada 26 Februari lalu, Di seluruh negeri, termasuk wilayah administrasi khusus Hong Kong dan Makau, lebih dari 233 juta siswa tidak sekolah karena virus. Jepang yang memiliki hampir 16,5 juta siswa yang dipindahkan, menurut data UNESCO Institute of Statistics. Sejumlah sekolah di Amerika Serikat telah membatalkan kelas akibatCOVID-19 (Purwanto et.all, 2020:2).

Selain dunia pendidikan, COVID-19 juga menghambat pekerjaan manusia secara umum mulai dari level swasta hingga pada tingkatan organisasi pemerintah. Dimana mereka diwajibkan untuk tetap tinggal di rumah dan tidak melakukan interaksi sosial dengan orang luar terkecuali keluarga yang tinggal dalam satu rumah, itu pun harus bisa menjaga jarak ketika salah seorang keluarga pernah melakukan aktivitas di luar rumah.

Keluarga juga memiliki risiko penularan COVID-19 apabila ada salah satu anggota keluarga terinfeksi dan menularkan ke anggota keluarga lainnya, sehingga satu rumah tangga tertular COVID-19 saat berada di rumah.

Pada gambar 1, memperlihatkan hal hal sebagai berikut: 1) Transmisi COVID-19 telah masuk ke satuan unit terkecil, yaitu keluarga. Segala kebijakan, sistem, dan protokol yang diterapkan pemerintah tidak mampu mencegah transmisi COVID-19 ke keluarga; 2) Lingkup sosial budaya Indonesia yaitu mengutamakan silahturahmi, menyebabkan transimisi COVID-19 dari satu keluarga 


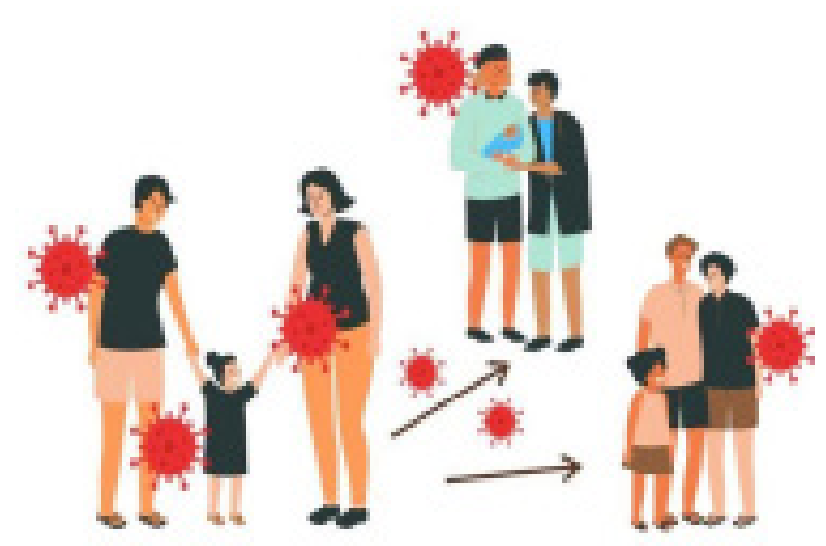

Gambar 1. Penyebaran COVID-19 di Keluarga Sumber: Hasil olahan peneliti (2020)

mempermudah penularan ke keluarga lainnya; dan 3) Warga yang memiliki gejala enggan melakukan rapid test atau SWAB karena takut stigma negatif dan dikucilkan oleh masyarakat.

Berkaitan dengan COVID-19 yang sudah menyebar hampir seluruh masyarakat di berbagai belahan dunia, berdasarkan data WHO (2020) bahwa Indonesia juga memberikan konfirmasi bahwa terdapat dua orang warga telah terinfeksi COVID-19 saat mengikuti acara di Jakarta. Penderita awalnya melakukan kontak langsung dengan Warga Negara Asing (WNA) asal Jepang yang tinggal di Malaysia. Setelah melakukan pertemuan, dua warga negara Indonesia tersebut mengeluhkan demam, batuk, dan sesak napas (Yuliana, 2020:188). Tidak lama berselang dari dua korban tersebut kemudian semakin bertambah dari hari ke hari.

Pencegahan penyebaran COVID-19, pemerintah Indonesia mengambil beberapa langkah seperti mensosialisasikan gerakan social distancing, yaitu dengan menjaga jarak aman dengan manusia lainnya minimal 2 meter, dan tidak melakukan kontak langsung dengan siapapun, serta menghindari pertemuan massal (CNN Indonesia, 2020). Langkah selanjutnya ialah penggunaan masker kain yang apabila dibuat dan digunakan dengan tepat dapat menjadi penghalang bagi droplet yang dikeluarkan pemakainya ke udara dan lingkungan.
Penggunaan masker harus menjadi bagian dari rangkaian langkah-langkah pencegahan, yang mencakup sering membersihkan tangan, penjagaan jarak fisik jika memungkinkan, etiket batuk dan bersin, serta pembersihan lingkungan. Menghindari kerumunan padat di ruang tertutup, terutama jika penjagaan jarak fisik tidak memungkinkan, dan memastikan ventilasi lingkungan yang baik di setiap tempat tertutup, (World Health Organization, 2020).

Pemerintah melakukan upaya dalam mencegah terjadinya penyebaran COVID-19 bertujuan untuk melindungi seluruh warga negara Indonesia. Langkah-langkah yang diambil umumnya ditujukan kepada setiap individu agar sadar bahwa menyebaran COVID-19 merupakan masalah yang sangat kompleks karena dapat menghambat hampir seluruh aktivitas manusia yang umumnya lebih banyak melakukan interaksi dengan manusia lainnya dan tentunya mempermudah penyebaran virus. Berdasarkan data bahwa pada akhirnya dikonfirmasi terkait dengan transmisi pneumonia COVID-19 dapat menular dari manusia ke manusia(Yuliana, 2020).

Berbagai macam upaya atau langkah yang dibuat oleh pemerintah ternyata masih banyak ditemukan warga yang tidak patuh dengan himbauan-himbauan tersebut seperti tidak rajin mencuci tangan, tidak menggunakan masker, menjaga jarak dan tidak bersentuhan. Pelangaran-pelanggaran yang dilakukan oleh masyarakat tentunya membuat pemerintah mengambil tindakan tegas seperti membuat pos penjagaan kesehatan diberbagai daerah perbatasan baik lintas kabupaten atau kota dan lintas provinsi. Masyarakat yang melakukan perjalanan jauh seperti melewati darat, laut, dan udara harus memiliki surat keterangan berbadan sehat dari puskesmas atau rumah sakit. Surat itu ditandai dengan adanya Rapid Test. Hal inilah yang terjadi di Desa Nupabomba sebagai daerah perbatasan antara Kabupaten Donggala dan Kota Palu. Di desa tersebut juga merupakan jalur lintas provinsi dari Sulawesi Tengah ke 
Makasar, Gorontalo, dan Menado, sehingga masyarakat merasa lebih waspada dan harus lebih berhati-hati saat bertemu dengan orang baru yang merupakan masyarakat dari luar daerah.

Terkait dengan masalah COVID-19, tentunya upaya pemerintah untuk mencegah terjadinya penyebaran virus juga harus didukung oleh masyarakat luas. Hal ini orangtua yang memiliki peran penting dalam melindungi anak-anaknya agar tetap terjaga dengan aman dan hidup sehat terbebas dari COVID-19. Melindungi anak dapat dilakukan dengan banyak hal, seperti mempersuasi anak untuk mengkonsumsi makanan yang bergizi dan bernutrisi. Penelitian yang dilakukan oleh Wardyaningrum (2010) mengenai pola komunikasi keluarga dalam menentukan konsumsi nutrisi bagi anggota keluarga. Penelitian tersebut menjelaskan bahwa pola asuh keluarga termasuk pola komunikasi orang tua dalam menyampaikan pesan-pesan dan mencontohkan perilaku tentang konsumsi nutrisi sehari-hari juga menentukan perilaku anak. Hasil penelitian tersebut ditemukan bahwa pengetahuan ayah dan ibu tentang nutrisi sangat standart, meskipun diantara keluarga memiliki sumber daya pangan yang dihasilkan sendiri seperti tanaman sayuran dan karbohidrat serta mampu memperoleh protein dari telur dan susu, namun tidak nampak adanya kreativitas dalam membuat varian makanan. Pengetahuan yang standar dari orang tua membuat anak tidak mampu untuk berkreativitas dalam mengolah makanan untuk anak-anaknya agar bisa hidup sehat. Pengetahuan orang tua yang baik terhadap nutrisi makanan tentunya berpengaruh terhadap pola makan anak. Ini menandakan bahwa komunikasi persuasif orangtua berlangsung dengan efektif. Perilaku tentang konsumsi makanan yang diajarkan oleh orangtua bisa juga berkaitan dengan budaya yang dimiliki secara turun-temurun dalam keluarga inti.

Rochayanti, Pujiastuti, Warsiki (2012) menjelaskan bahwa keluarga merupakan organisasi sosial terkecil dalam masyarakat yang mempunyai peranan penting terutama tahapan membentuk dan mengembangkan karakter anak selama periode awal kehidupan anak. Keluarga memberikan pengaruh budaya kepada anak dalam pembentukan sikap pertama dan ketertarikan mereka pada segala hal yang ada disekitar. Pengaruh budaya tersebut seperti kebiasaan konsumsi makanan yang bergizi bertujuan untuk menjadikan anak hidup sehat dan terbebas dari penyakit, seperti fenomena bencana non-alam yang terjadi saat ini ialah penyebaran COVID-19 yang juga bisa dicegah dengan makan makanan bergizi atau bernutrisi.

Penyebaran COVID-19 di Indonesia yang dapat menyebabkan kematian, tentunya membuat orangtua sigap dalam bertindak, khususnya bagi mereka yang tinggal di daerah perbatasan seperti di Desa Nupabomba. Komunikasi yang dilakukan oleh orangtua terhadap anak-anaknya, umumnya lebih banyak membahas tentang cara mencegah COVID-19 agar tidak menginfeksi tubuh. Selain mengikuti dan menyampaikan pesan-pesan positif dalam komunikasi keluarga terkait dengan himbauan pemerintah seperti mencuci tangan, menggunakan masker, menjaga jarak dan tidak bersentuhan, hal menarik yang juga mereka lakukan ialah dengan sering mengingatkan anggota keluarga mereka seperti anak-anak agar jangan melakukan komunikasi dengan orang lain, khususnya pada individu yang berasal dari luar daerah seperti Menado, Gorontalo dan Makasar.

Tidak hanya pada masyarakat yang berasal dari tiga provinsi di pulau Sulawesi, orangtua di Desa Nupabomba juga memempersuasif dan melarang anak-anaknya agar tidak berinteraksi dengan masyarakat yang berasal dari Kota Palu, Banggai dan Buol. Hal ini dikarenakan korban COVID-19 di Sulawesi Tengah yang paling banyak berasal dari tiga daerah tersebut. Larangan yang disampaikan orangtua pada anak-anaknya merupakan bentuk komunikasi keluarga yang di dalamnya terdapat kepedulian dan tentunya rasa saling menjaga antara orangtua ke anak dan sebaliknya. 


\section{Komunikasi Keluarga}

Komunikasi di dalam sebuah keluarga adalah penyampaian pesan dari ayah, ibu, orang tua, anak, suami, isteri, mertua, kakek, nenek maupun sebaliknya sebagai penerima pesan. Pesan yang disampaikan dalam komunikasi tersebut dapat berupa informasi, nasehat, petunjuk, pengarahan, maupun meminta bantuan. Komunikasi yang terjadi dalam keluarga merupakan suatu komunikasi yang unik, dan komunikasi yang terjadi didalam keluarga tentu akan melibatkan paling sedikit dua orang yang mempunyai sifat, nilai-nilai, pendapat, sikap, pikiran dan perilaku yang khas dan berbeda-beda, (Rahmah, 2018:15). Berkaitan dengan peran orangtua, menjelaskan bahwa menjadi orang tua yang baik, kemudian membutuhkan lebih dari sekedar intelektualitas, melainkan juga menyentuh dimensi kepribadian dan melibatkan emosi (Gottman \& DeClaire, 1997).

Menurut Departemen kesehatan RI menyatakan bahwa ada beberapa peran dan tanggung jawab keluarga, yaitu: melanjutkan keturunan, membangun saling mencintai dan memiliki, mengelola sumbersumber ekonomi keluarga, melindungi dari penyakitpenyakit sosial seperti penyalahgunaan napza atau penganiaan anak, pendidikan dan pembiayaan, istirahat dan rekreasi yang tidak membahayakan perkembangan fisik dan mental, nilai-nilai agama/ spiritual, dan kedudukan sosial. Komunikasi, baik verbal maupun nonverbal pada dasarnya merupakan salah satu aspek yang penting dalam proses pendidikan remaja, dan merupakan sumber-sumber rangsangan untuk membentuk konsep dirinya.

Komunikasi keluarga adalah komunikasi yang terjadi dalam sebuah keluarga, yang merupakan cara seorang anggota keluarga untuk berinteraksi dengan anggota lainnya, sekaligus sebagai wadah dalam membentuk dan mengembangkan nilainilai yang dibutuhkan sebagai pegangan hidup. Pegangan hidup anak berguna agar anak dapat menjalani hidupnya ketika berada dalam lingkungan masyarakat, apa yang terjadi jika sebuah pola komunikasi keluarga tidak terjadi secara harmonis tentu akan mempengaruhi perkembangan anak, (Ammang, Sondakh \& Kalesaran, 2017: 2)
Komunikasi keluarga menjadi salah satu bentuk dari hubungan komunikasi antar pribadi. Komunikasi ini menjadi penting untuk dilihat lebih dekat karena, 1) keluarga adalah tempat di mana orang dewasa dan remaja mengalami bagian terbesar dari hubungan antarpribadi paling penting dan intim, 2) keluarga adalah agen sosialisasi utama, di mana keahlian komunikasi dan hubungan didapatkan dari keluarganya (Kusuma, 2017:49). Keahlian komunikasi dalam hal ini dimaknai sebagai cara untuk mempersuasi sehingga dapat mengubah pemahaman dan perilaku, seperti halnya komunikasi yang dilakukan orangtua dalam mempersuasi anak untuk mencegah terjadinya penyebaran COVID-19.

\section{Elaboration Likelihood Theory}

Individu seringkali memberikan perhatian yang serius terhadap suatu masalah namun hanya memberikan perhatian selintas terhadap masalah lain. Hal ini terlihat bahwa individu terkadang sangat mempertimbangkan sesuatu dengan memikirkannya dengan sangat matang sementara. Teori yang memberikan perhatian terhadap masalah ini dinamakan Teori Kemungkinan Elaborasi (Elaboration Likelihood Theory).

Teori ELT dikembangkan oleh Richard Petty dan John Cacioppo. Teori ini pada dasarnya adalah teori mengenai persuasi karena mencoba memperkirakan kapan dan bagaimana seseorang dapat atau tidak dapat mengubah pendapat karena dibujuk oleh adanya suatu pesan atau argumen yang diterimanya. Teori ELT menjelaskan berbagai cara yang dilakukan orang ketika mengevaluasi informasi yang diterimanya. Terkadang orang mengevaluasi suatu informasi dengan cara yang rumit dengan menggunakan pemikiran namun terkadang informasi dievaluasi melalui cara yang sederhana dengan tidak atau kurang menggunakan pemikiran kritis. Terkadang orang sangat memikirkan suau argumen namun terkadang tidak.

Menurut teori "Kemungkinan Elaborasi" (Elaboration Likelihood Theory), cara orang memproses suatu informasi terdiri atas dua cara. 
Pertama, membawa informasi itu melalui jalur sentral atau jalur pusat (central route) dan kedua, membawa informasi itu melalui jalur periferal atau jalur pinggiran (peripheral route). Kedua jalur tersebut berada dalam otak manusia. Elaborasi atau pemikiran kritis terjadi padajalur sentral otak manusia, sedangkan pada pemikiran yang kurang kritis terjadi pada jalur periferal (Littlejohn and Foss, 2011), yaitu: 1) Jalur sentral (central route), yaitu mengelola informasi yang diterima melalui jalur sentral, maka secara aktif memikirkan informasi itu dan mempertimbangkannya dengan memperhatikan informasi lain yang sudah dimiliki sebelumnya. Penggunaan jalur sentral mempertimbangkan suatu argumen atau informasi dengan hati-hati dan apabila pandangan berubah karena informasi atau argumen yang diterima, maka hal itu terjadi setelah melalui "perjuangan" panjang yang terjadi di dalam otak. Perubahan pandangan ini bersifat lebih permanen dan biasanya diikuti dengan perubahan tingkah laku; 2) Jalur pinggiran (peripheral route), yaitu mengolah suatu informasi melalui jalur pinggiran, maka menjadi kurang krites terhadap informasi yang anda terima itu. Perubahan yang terjadi bersifat sementara (temporal), sehingga pengaruhnya terhadap perubahan tingkah laku sangat minimal. Teori ini menyatakan bahwa seseorang menggunakan pemikiran kritis bergantung pada dua faktor umum yaitu motivasi dan kemampuan.

Masalah yang terjadi terkait dengan COVID-19 yang dicegah melalui komunikasi leluarga, maka penelitian ini bertujuan untuk menganalisis komunikasi keluarga dalam pencegahan COVID-19 pada masyarakat Desa Nupabomba sebagai daerah perbatasan Kabupaten Donggala dan Kota Palu.

\section{Metode Penelitian}

Penelitian ini menggunakan metode kualitatif dengan pendekatan studi kasus COVID-19. Lokasi penelitian dilakukan di Desa Nupabomba sebagai desa perbatasan antara Kabupaten Donggala dan Kota Palu. Di daerah perbatasan tersebut kemudian dibuat pos penjagaan kesehatan COVID-19. Subjek penelitian terdiri dari 10 rumah tangga yang terbagi atas lima dusun di Desa Nupabomba. Objek penelitian berkaitan dengan komunikasi keluarga dalam pencegahan COVID-19 di Desa Nupabomba.

Teknik pengumpulan data: 1) observasi, peneliti melakukan observasi partisipasi pasif dimana peneliti berada di luar subjek dan tidak ikut dalam kegiatan-kegiatan yang ada di dalamnya, hanya berfokus pada aktivitas yang berkenaan dengan permasalahan penelitian tentang COVID-19; 2) wawancara mendalam dilakukan peneliti kepada beberapa masyarakat di Desa Nupabomba yang terbagi atas lima dusun; dan 3) studi pustaka dari jurnal yang relevan dengan penelitian ini. Teknik analisis data dalam penelitian ini yaitu reduksi data yang terkait dengan COVID-19, pengumpulan data, dan penarikan kesimpulan terkait dengan pola komunikasi keluarga di Desa Nupabomba dalam mencegah terjadinya penyebaran COVID-19.

\section{Hasil Penelitian dan Pembahasan}

Desa Nupabomba merupakan salah satu daerah yang masuk dalam wilayah Kabupaten Donggala dan berbatasan langsung dengan wilayah Kota Palu, Provinsi Sulawesi Tengah. Desa Nupabomba merupakan daerah jalur lintas darat antar provinsi seperti Sulawesi Utara, Gorontalo dan Sulawesi Selatan. Pemerintah kemudian menerapkan sebuah kebijakan dengan membuat pos penjagaan kesehatan dalam mencegah terjadinya COVID-19 yang dibawa oleh masyarakat pendatang dari tiga provinsi tersebut. Pos tersebut, masyarakat yang memasuki wilayah ke Kota Palu Sulawesi Tengah dari berbagai kabupaten diperiksa dengan sangat teliti mulai dari surat keterangan sehat yang di dalamnya terdapat hasil Rapid test.

Berdasarkan data hasil wawancara kepada salah seorang warga Desa Nupabomba yang merupakan petugas kesehatan di pos penjagaan COVID-19 menjelaksan bahwa bagi masyarakat 
pendatang dari berbagai kabupaten di Sulawesi Tengah dan masyarakat pendatang dari provinsi lain diwajibkan memeriksakan kesehatan, seperti cek suhu tubuh di pos penjagaan COVID-19 dan juga harus menyertakan hasil Rapid test. Hal ini harus dilakukan dengan sangat teliti dikarenakan COVID-19 merupakan virus yang sangat berbahaya dan dapat menyebabkan kematian. Berdasarkan data sekunder yang didapatkan oleh peneliti bahwa kasus kematian yang disebabkan oleh COVID-19 yaitu lebih banyak terjadi pada orangtua dengan penyakit penyerta. Kasus kematian pertama pasien lelaki usia 61 tahun dengan penyakit penyerta tumor intra abdomen dan kelainan di liver (Yuliana, 2020:188).

Tingkat kematian dan korban yang telah terjangkit COVID-19 tentunya tidak hanya terjadi di negara-negara lain di Eropa, dan Amerika. Asia seperti Indonesia proses penyebaran COVID-19 juga sangat cepat dan menelan banyak korban meninggal. Hingga saat ini pada tanggal 26 Maret 2020 tercatat 893 kasus terinfeksi virusi COVID-19. Provinsi Sulawesi Tengah pada tanggal 26 Maret 2020 merupakan hari pertama pengumuman satu pasien terinfeksi COVID-19 di rumah sakit Undata Palu. Pemberitaan kasus COVID-19 tersebut tentunya sangat mengkhawatirkan bagi masyarakat, sehingga pemerintah daerah Sulawesi Tengah menerapkan dan memperketat kebijakan atau peraturan untuk pencegahan virus.

$$
\text { Pedoman Kesiapsiagaan Menghadapi }
$$
Coronavirus Disease (COVID-19) Revisi ke-3 yang disampaikan langkah-langkah yang paling efektif di masyarakat (Depkes, 2004), meliputi: 1) Melakukan kebersihan tangan menggunakan hand sanitizer jika tangan tidak terlihat kotor atau cuci tangan dengan sabun jika tangan terlihat kotor; 2) Menghindari menyentuh mata, hidung, dan mulut; 3) Terapkan etika batuk atau bersin dengan menutup hidung dan mulut dengan lengan atas bagian dalam atau tisu, lalu buanglah tisu ke tempat sampah; 4) Pakailah masker medis jika memiliki gejala pernapasan dan melakukan kebersihan tangan setelah membuang masker; 5) Menjaga jarak (minimal 1 meter) dari orang yang mengalami gejala gangguan pernapasan.

Berikut hasil wawancara peneliti dengan beberapa orangtua sebagai narasumber dari Desa Nupabomba menyatakan bahwa untuk mencegah terjadinya pencegahan COVID-19, mereka selalu menerapkan himbaun pemerintah seperti mencuci tangan dan jaga jarak. Himbauan tersebut juga selalu disampaikan dari orangtua kepada anakanak dengan bahasa yang mudah dimengerti dan dipraktekan. Orangtua merupakan keluarga inti yang memiliki ikatan emosional sangat dekat terhadap anak dan intensitas pertemuan yang selalu terjadi hampir 24 jam. Anak-anak sebagai informan pendukung menjelaskan bahwa selalu diingatkan orangtua agar tetap menjaga kebersihan tubuh dan menjaga jarak, namun hanya pada orang yang tidak dikenali. Ini menandakan bahwa anak-anak masih sangat mempercayai bahwa orang-orang yang dikenali (tetangga sendiri) tidak terinfeksi COVID-19. Berikut kutipan wawancara dengan narasumber X1:

"Karena kami tinggal di desa, jadi kami masih sangat kenal orang-orang di sini dan kami tidak khawatir dengan mereka, karena umumnya mereka kerjanya juga di desa sini, tidak keluar kemana-mana, apalagi corona begini, jadi kami membebaskan anak-anak berinteraksi dengan siapapun warga di sini, karena kalau dibatasi juga, takutnya ada ketersinggungan sesama tetangga, dan ini yang bisa merusak tali silahturahmi nantinya. Intinya kami hanya waspada dengan pendatang baru" (Narasumber X1, 28 Maret 2020).

Data wawancara menjelaskan bahwa untuk menjaga jarak, cukup dengan orang yang tidak dikenali, sedangkan pada tetangga dibebaskan berinteraksi seperti biasanya. Hal ini dilakukan agar tidak terjadi ketersinggungan dalam hidup bertetangga. Hal ini orangtua mengajarkan kepada anak untuk tetap menjaga kehidupan yang harmonis, karena disisi lain kehidupan 
masyarakat di desa umumnya hanya dilakukan di desa saja yang lebih banyak masyarakatnya bekerja di kebun, berternak, penambang pasir, petani, dan lain-lain. Masyarakat sangat jarang melakukan interaksi di luar desa dan tentunya tidak bertemu dengan orang lain yang berasal dari daerah terpapar COVID-19 dan masuk dalam kategori zona merah seperti Kota Palu.

Terkait dengan pencegahan COVID-19, salah satu narasumber mengatakan bahwa pesan-pesan positif yang digunakan untuk mengingatkan anak-anak agar tetap terjaga kesehatan tubuh dan terbebas dari COVID-19 ialah dengan "tetap berada di rumah dan mengurangi aktivitas di luar rumah". Hal ini dilakukan karena mengingat banyaknya masyarakat pendatang yang lalu lalang melewati jalur Desa Nupabomba sebagai daerah jalan trans Sulawesi. Orangtua selalu mengingatkan anaknya agar waspada dengan tetap tinggal atau beraktivias di dalam rumah.

Pencegahan COVID-19 dengan cara tetap tinggal di rumah selalu diberitakan oleh berbagai media dan disampaikan oleh narasumbernarasumber yang berkompeten di bidangnya seperti penyampaian dari dokter Reisa Broto Asmoro seorang Dokter Umum menyampaikan bahwa semua orang harus menjaga gaya hidup bersih dan sehat, makanan yang seimbang, istrahat yang cukup, rutin olahraga, jangan panik, dan jangan stres dan tetap di rumah saja. Dokter Tirta Mandira Hudi yang merupakan seorang Dokter Relawan menyampaikan bahwa ketika berpergian dan pulang kerumah yang dilakukan pertama kali ialah mencuci tangan, muka, dan yang lainnya terlebih dahulu dan maksimalkan untuk tetap dirumah saja.

Kalimat tetap tinggal di rumah pada dasarnya merupakan "pesan persuasif" yang bertujuan untuk mengakomodir semua masyarakat tanpa terkecuali agar tidak melakukan aktivitas di luar rumah, apalagi aktivitas tersebut harus bertemu dan berkumpul dengan banyak orang yang tentunya memberikan resiko tinggi terinfeksi COVID-19. Himbauan dari pemerintah terkait kalimat di rumah saja, juga sering disampaikan orangtua terhadap anak dalam setiap proses komunikasi keluarga yang terjadi. Hasil wawancara narasumber X2: "Kami ini takut dengan larangan orangtua, jadi lebih banyak tinggal di rumah supaya virus tidak terjangkit di tubuh kami. Kalau di rumah kami bisa melakukan banyak hal seperti membantu pekerjaan orangtua khususnya mama. Yah kalau anak perempuan beres-beres rumah, mencuci dan lain-lain. Kalau anak laki-laki sama juga. Tidak hanya itu, dengan tetap di rumah saja, kami dan orangtua sering bercanda yang membuat hati kami gembira dan senang" (Narasumber X2, 29 Maret 2020).

Kutipan wawancara di atas menyatakan bahwa tetap tinggal di rumah adalah cara untuk dapat mencegah terjadinya penyebaran COVID-19. Berada di rumah masih dapat melakukan berbagai macam aktivitas mulai dari belajar mandiri, membantu pekerjaan orangtua dan lain-lain. Pada dasarnya pesan yang disampaikan orangtua mampu diterapkan dengan baik oleh anak. Tetap tinggal di rumah, proses komunikasi keluarga yang terjalin sangat baik karena banyak diselipkan candaan-candaan yang membuat antara anak dan orangtua menjadi senang dan gembira sehingga dapat membuat hubungan menjadi lebih harmonis. Berdasarkan konsep yang ada dijelaskan bahwa komunikasi keluarga memiliki banyak aspek sebagai unsur pembentuk terciptanya relasi harmonis bagi semua peserta komunikasi yang terlibat di dalamnya. Semua peserta komunikasi memiliki peran dan memberikan warna serta pengaruh bagi terciptanya relasi anggota keluarga yang hangat dan menggembirakan, (Priliantari, Rustanta, \& Seyawati. 2017:16). Relasi yang baik juga berdampak pada keterbukaan anak dan orangtua sebagai keluarga inti. 
Terkait dengan keterbukaan, penelitian yang dilakukan Hastasari, Aw, dan Hajaroh (2018) mengenai pola komunikasi keluarga dalam mencegah kenakalan pelajar SMA di kota Yogyakarta. Penelitian tersebut menjelaskan bahwa keluarga melalui penerapan pola komunikasi yang tepat antara orangtua dan anak dapat menjadi tempat terjadinya interaksi penyampaian dan penerimaan pesan secara efektif, sehingga terbentuklah keterbukaan dan keterusterangan antar anggota keluarga. Komunikasi keluarga yang baik pada dasarnya mampu "mempersuasi" anggotanya untuk bertindak secara positif. Pesan yang disampaikan mudah untuk dipahami dan bersifat unik, karena orangtua mampu mengetahui karakteristik dari anakanaknya ataupun sebaliknya, anak ke orangtua.

Pesan persuasif yang unik tersebut berdasarkan data dari semua narasumber (orangtua) menyatakan bahwa: "Kami orangtua, khususnya bagi ibu-ibu sangat melindungi anak-anaknya, misalnya, mengajarkan kepada mereka untuk tidak menerima tamu yang tidak di kenal, serta kalau di luar rumah, kami suruh anak-anak kami lari dan jangan mendekat dengan orang baru. Apalagi orang-orang itu dari daerah zona merah seperti Makassar. Karena daerah kami ini jalur trans Sulawesi." (Narasumber X3, 29 Maret 2020)

Kutipan wawancara tersebut menjelaskan bahwa menjaga jarak itu adalah tindakan yang sangat penting, mulai dari jarak kurang lebih 1-2 meter hingga pada jarak yang lebih ekstrim yaitu tidak menerima tamu dan berupaya untuk lari atau menjauh jika ada masyarakat yang tidak dikenal mendekat. Kalimat ini sangat sering disampaikan dan diikuti oleh hampir semua anak di Desa Nupabomba. "Kami diajarkan orangtua, harus bisa jaga jarak, tidak menerima tamu dari luar, apa lagi yang tidak dikenal. Kami kalau liat orang baru yang mendekat, kami langsung lari. Karena kami takut terjangkit corona-19 di bawa ke rumah sakit, habis itu sakit lalu mati. Karena jujur daerah kami ini banyak lewat busbus trans yang dari Manado, Makassar dan Gorontalo" (Narasumber X4, 29 Maret 2020)
Upaya mandiri untuk melindungi diri dari penyebaran COVID-19 ialah menjaga jarak dengan cara menjauhi orang-orang yang tidak dikenali, terlebih yang berasal dari kabupaten dan provinsi lain. Menjauhi yaitu sama dengan berlari menuju rumah dan tidak menerima siapapun tamu asing yang datang. Tindakan ini sangat sering dilakukan, ini menandakan bahwa pesanpesan antarpribadi dalam lingkungan keluarga yang disampaikan orangtua pada dasarnya merupakan bentuk sosialisasi yang berhasil mempersuasi anak-anak mereka. Berdasarkan konsep komunikasi keluarga yang menjadi salah satu bentuk dari hubungan komunikasi antarpribadi menyatakan bahwa komunikasi ini menjadi penting untuk dilihat lebih dekat karena keluarga adalah agen sosialisasi utama, di mana keahlian komunikasi dan hubungan didapatkan dari keluarganya, (Kusuma, 2017:49).

Informasi terkait dengan bahaya COVID-19 yang diterima oleh orangtua dan anak tentunya harus dilakukan pencegahan yang maksimal. Tindakan-tindakan pencegahan tersebut yang diterapkan oleh orangtua dan anak merupakan bentuk kesadaran diri agar bisa hidup sehat. Orangtua dalam penelitian ini berperan penting dalam memberikan pesan-pesan persuasi terhadap anak, sehingga dalam hasil penelitian secara umum bahwa masalah COVID-19 sangat penting dan harus dicegah mulai dari diri sendiri. Hal ini bertujuan agar dapat melindungi orang lain seperti keluarga inti dan masyarakat disekitarnya.

Informasi yang dianggap penting dan harus diterapkan dengan baik, jika ditinjau berdasarkan Teori Elaboration Likelihood Theory masuk dalam konsep jalur sentral (central route). Informasi yang diterima melalui jalur sentral, maka secara aktif memikirkan informasi itu dan mempertimbangkannya dengan memperhatikan informasi lain yang sudah dimiliki sebelumnya. Penggunaan jalur sentral untuk mempertimbangkan suatu argumen atau informasi dengan hati-hati, dan 


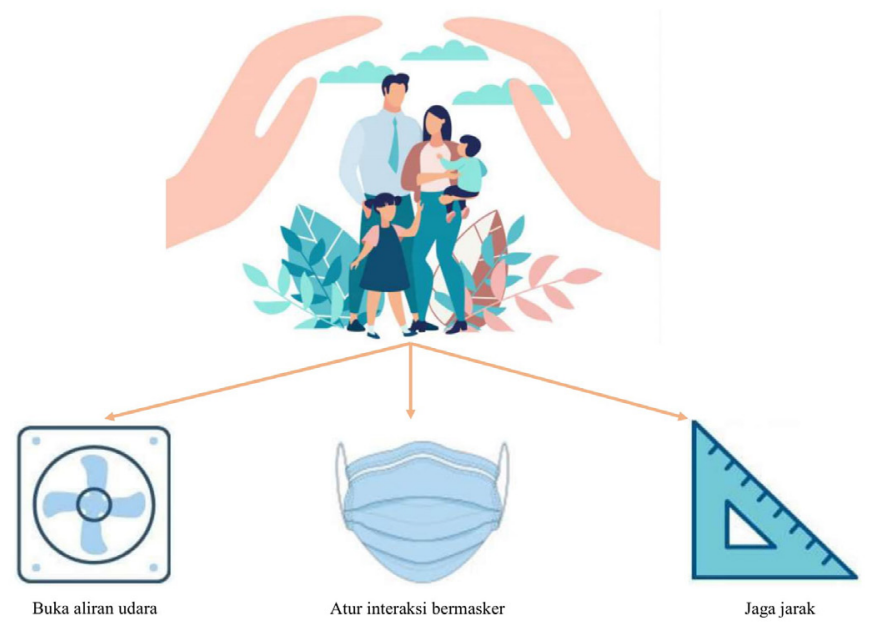

Gambar 2. Informasi penting untuk disosialisasikan kepada keluarga

Sumber: Hasil analisis peneliti (2020)

pada akhirnya pandangan berubah karena informasi atau argumen yang anda terima, maka hal itu terjadi setelah melalui "perjuangan" panjang yang terjadi di dalam otak. Perubahan pandangan ini bersifat lebih permanen dan biasanya diikuti dengan perubahan tingkah laku. Artinya bahwa jalur sentral merupakan jalur yang sangat penting, informasi yang melewati jalur tersebut tentunya merupakan informasi yang dianggap penting (Littlejohn \& Foss, 2011). Terkait informasi yang penting untuk disosialisasikan kepada para keluarga, dapat dilihat pada gambar 2 .

Pada gambar 2 memerlihatkan temuan hasil penelitian dan pembahasan tentang beberapa hal yang harus disosialisasikan dan ditaati oleh setiap keluarga untuk mengurangi risiko COVID-19. Hal-hal tersebut, yaitu: 1) Meminimalisir risiko dengan memerhatikan ventilasi (buka jendela dan pintu) agar udara segar mengalir, hindari dalam ruangan tertutup khususnya pada keluarga yang rentan; 2) Mengatur interaksi dengan menyediakan kamar terpisah jika ada anggota keluarga yang mengalami gejala COVID-19 dan bekerja di luar rumah, serta mengurangi interaksi dengan anggota yang rentan, dan menggunakan masker, khususnya disekitar lansia dan balita; dan 3) Jaga Jarak, jika memungkinkan anggota keluarga yang bekerja di luar rumah dan menjaga social distancing.

\section{Simpulan}

Berdasarkan dari hasil penelitian, dapat disimpulkan bahwa komunikasi keluarga yang digunakan oleh orangtua dan anak sangat bermanfaat dalam mencegah terjadinya penyebaran COVID-19 di Sulawesi Tengah. Proses penyampaian pesan terkait dengan bahaya COVID-19 yang dilakukan orangtua dapat mengubah pemahaman dan perilaku anak sehingga terjadilah tindakan pencegahan. Hal ini dilakukan oleh orangtua karena menganggap bahwa informasi terkait dengan virus tersebut sangat penting ini, apabila diabaikan dapat menyebabkan tubuh menjadi sakit ringan hingga pada kematian. Pencegahan yang dilakukan seperti rajin mencuci tangan, memakai masker, tidak bersentuhan dan menjaga jarak, seperti menjauhi para pendatang atau masyarakat lain yang melewati Desa Nupabomba.

Penelitian ini memberikan kontribusi berupa rekomendasi kepada setiap keluarga agar dapat mematuhi prokol kesehatan dan selalu menyosialisasikan kepada anggota keluarga dan masyarakat membiasakan hidup sehat dengan cara membuka aliran udara setiap ruang di dalam rumah, mengatur interaksi dengan menggunakan masker, dan jaga jarak dalam kegiatan di rumah maupun di luar rumah. 


\section{Ucapan Terima Kasih}

Terima kasih kami ucapkan kepada masyarakat Desa Nupabomba yang sudah berkenan menjadi narasumber dan memberikan data penelitian yang sangat bermanfaat bagi kami dan orang lain terkait dengan strategi yang dilakukan untuk pencegahan COVID-19.

\section{Daftar Pustaka}

Ammang, W., Sondakh, M., \& Kalesaran, E. R. (2017). Peran Komunikasi Keluarga Dalam Mengatasi Perilaku Merokok PadaAnak Usia Remaja (Studi Pada Masyarakat Kelurahan Kampung Makassar Timur Kota Ternate). Acta Diurna Komunikasi, 6(1). Diakses dari https://ejournal.unsrat.ac.id/index.php/ actadiurnakomunikasi/article/view/15496

Depkes R.I (2004). Modul Untuk Pemberdayaan Orang Tua Dalam Mencegah Penyalahgunaan Nafza.

Dewi, W. A. F. (2020). Dampak Covid-19 Terhadap Implementasi Pembelajaran Daring Di Sekolah Dasar. EDUKATIF: Jurnal Ilmu Pendidikan, 2(1), 55-61. https://doi.org/10.31004/edukatif.v2i1.89

Gottman, J., \& DeClaire, J. (1998). Kiat-kiat Membesarkan Anak yang Memiliki kecerdasan Emosional. Tokoh. Hermaya: penerjemah. Jakarta: Gramedia Pustaka Utama Hastasari, C., Aw, S., \& Hajaroh, M. (2018). Pola Komunikasi Keluarga Dalam Mencegah Kenakalan Pelajar SMA di Kota Yogyakarta. INFORMASI: Kajian Ilmu Komunikasi, 48(2), 155-168. https:// doi.org/10.21831/informasi.v48i2.22389 Huang C, Wang Y, Li X, Ren L, Zhao J, Hu Y, et al. (2020). Clinical features of patients infected with 2019 novel coronavirus in Wuhan, China. The Lancet, 395(10223), 497-506. https:// doi.org/10.1016/S0140-6736(20)30183-5
Kusuma, R. S. (2017). Komunikasi Antar Pribadi Sebagai Solusi Konflik Pada Hubungan Remaja Dan Orang Tua Di Smk Batik 2 Surakarta. Warta LPM, 20(1), 49-54. https://doi.org/10.23917/warta.v19i3.3642 Littlejohn, Stephen W., \& Foss, K. A. (2011). Theories Of Human Communication, Tenth Edition. USA: Waveland Press, Inc. Priliantari, Y. D., Rustanta, A., \& Setyawati, R. K. (2017). Dinamika Komunikasi Dalam Keluarga. Jurnal Ilmu Komunikasi dan Bisnis, 3(1), 15-24. Diakses dari http://jurnal.stiks-tarakanita. ac.id/index.php/JIK/article/view/156 Purwanto, A., Pramono, R., Asbari, M., Hyun, C., Wijayanti, L., Putri, R., \& santoso, priyono. (2020). Studi Eksploratif Dampak Pandemi COVID-19 Terhadap Proses Pembelajaran Online di Sekolah Dasar. EduPsyCouns: Journal of Education, Psychology and Counseling, 2(1), 1-12. Diakses dari https://ummaspul.ejournal.id/Edupsycouns/article/view/397

Rahmah, S. (2018). Pola Komunikasi Keluarga dalam Pembentukan Kepribadian Anak. Jurnal Alhadharah, 17(33), 13-31. http://dx.doi. org/10.18592/alhadharah.v17i33.2369 Rochayanti, C., Pujiastuti, E. E., \& Warsiki, A. (2012). Sosialisasi Budaya Lokal dalam Keluarga Jawa. Jurnal Ilmu Komunikasi, 10(3), 308-320. Diakses dari http://jurnal.upnyk.ac.id/index. php/komunikasi/article/view / 44 Rubson, B. (2020). COVID-19 Coronavirus Spike Protein Analysis For Synthetic Vaccines, a Peptidomimetic Antagonist, And Therapeutic Drugs, And Analysis Of A Proposed Achilles' Heel Conserved Region To Minimize Probability Of Escape Mutations And Drug Resistance. Comput. Biol. Med, 121, 103749. https://doi. org/10.1016/j.compbiomed.2020.103749 
Smith, F. M., \& Jones, W. (2004). The college student. In C. Wood \& M. Meyer (Eds.), Cross-cultural education (pp. 75-105). London, Canada: MacMillan. Susilo, A. et.all. (2020). Coronavirus Disease 2019: Tinjauan Literatur Terkini. Jurnal Penyakit Dalam Indonesia, 7(1), 45-67. http://dx.doi.org/10.7454/jpdi.v7i1.415

Wardyaningrum, D. (2010). Pola Komunikasi Keluarga dalam Menentukan Konsumsi Nutrisi bagi Anggota Keluarga. Jurnal Ilmu Komunikasi, 8(3), 289 - 298. Diakses dari http://jurnal.upnyk.ac.id/ index.php/komunikasi/article/view/137
World Health Organization. Coronavirus disease 2019 (COVID-19). (2020). Situation Report - 70 [Internet]. WHO; 2020 [updated 2020 March 30; cited 2020 March 31]. Available from: https:// www.who.int/docs/default-source/ coronaviruse/situation-reports/20200330sitrep-70-covid-19.pdf?sfvrsn=7e0fe3f8_2 Yuliana. Corona Virus Diseases (Covid-19): Sebuah Tinjauan Literatur. Wellness and Healthy Magazine, 2(1), 187-192. Diakses dari https://wellness.journalpress. id/wellness/article/view/21026 